S. Afr. J. Agric. Ext.

Vol. 44, No. 2, 2016: $158-166$

Foster, Fourie

DOI: http://dx.doi.org/10.17159/2413-3221/2016/v44n2a409

\& Neser.

\title{
A SURVEY OF LICK SUPPLEMENTATION AND MANAGEMENT PRACTICES OF COMMERCIAL BEEF FARMERS IN THE ZASTRON DISTRICT
}

\author{
Foster, L. A., ${ }^{33}$ Fourie, P. J. ${ }^{34} \&$ Neser, F. W. C. ${ }^{35}$
}

Correspondence Author: P. J. Fourie - Email: pfourie@cut.ac.za

\begin{abstract}
A study was conducted to determine the supplementation and management practices of commercial beef farmers. 48 commercial farmers from the Zastron district were selected for this study out of a prospective of 60 farmers that were bona fide commercial farmers and members of Free State Agriculture. The farmers reported the following calving percentage ranges: one farmer (2.1\%) between 50 and 59\%, three farmers $(6.3 \%)$ between 60 and $69 \%$, 19 farmers between 70 and 79\%, 22 farmers between 80 and $89 \%$ and three farmers between 90 and 99\%. Preventative vaccination was common practice as only one farmer did not vaccinate any of his cattle $(n=48)$. The provision of supplements seemed to be general practice $(100 \%, n=48)$ in the district as all the farmers gave some form of supplementation to their cattle. Only $22.9 \%(n=11)$ of the farmers provided supplements according to the production status of the animals and the main reason for not doing so is that $37.8 \%(n=14)$ of the respondents believed that it complicated management and $18.9 \%(n=7)$ thought it not necessary. It is believed that a lack of understanding of the function of supplements by some of the farmers in the district could be the cause of what could be considered as insufficient supplementation by animal nutritionists.
\end{abstract}

Keywords: Cattle, supplementation, licks, management, extension implication.

\section{INTRODUCTION}

There is probably no other agricultural sector where there is such a broad diversity of opinions and perspectives as in the beef industry in South Africa. These differences are often on the subject of breed, production systems, breeding, supplementation, management, marketing and all sorts of other sentimentality (Mentz, 2002:7).

Reproductive performance is the single most important economic trait in a beef cow herd (Melton, 1995:42; Walker \& Perry, 2007:1; Du Plessis, Hoffman \& Calitz 2006:30). As most components of fertility that influence calving and subsequent reproductive performance are not highly heritable, it is logical to assume that the majority of factors related to reproductive performance in cattle are influenced entirely by management (Patterson, Wood \& Randle 2002:204). The prime component of this management is believed to be the operating feeding conditions as body condition score at parturition has been implicated as the single most important factor affecting postpartum interval to estrus and pregnancy (Lishman, Lyle, Smith \& Botha 1984:12; Paisley \& Chichester, 2005:173 and Walker \& Perry, 2007:1).

\footnotetext{
33 Department of Agriculture, Central University of Technology Free State, Private Bag X20539, Bloemfontein, South Africa.

34 Department of Agriculture, Central University of Technology Free State, Private Bag X20539, Bloemfontein, South Africa. Email: pfourie@cut.ac.za

${ }^{35}$ Department of Animal, Wildlife and Grassland Sciences, University of the Free State, P.O. Box 339,

Bloemfontein, South Africa.
} 
Livestock farming under extensive conditions often necessitates the use of supplementary feeding as it may increase nutrient intake of the grazing ruminant and correct deficiencies in pastures (De Waal, 1990:1). Many reports have been published on the marked effect of supplementary feeding on animal reproduction and growth under extensive grazing conditions in certain areas and as a result supplementary feeding has become a general practice in the South African livestock farming industry (De Brouwer, Cilliers, Vermaak, Van der Merwe, \& Groenewald 2000:43; De Waal, Randall, \& Koekemoer, 1996:29; Lishman, Lyle, Smith \& Botha 1984:10; Read, Engels \& Smith 1986a:7; Read, Engels \& Smith 1986b:13 and Van Niekerk, 1996:51). The provision of feed to animals is however a major cost input in almost any animal production system (Lamb \& Maddock, 2009:1). As lick and feed cost is by far the most expensive cost item in a beef cattle system it is important that the results of this kind of study is conveyed to farmers. The role of agricultural extension is there. The aim of this survey was to quantify the management practices of beef cattle farmers in the Zastron district. The paper also stresses the important role of agricultural extension in transferring technical information to farmers.

\section{MATERIALS AND METHODS}

Forty-eight commercial farmers from the Zastron district were selected for this study out of a prospective of 60 farmers that were bona fide commercial farmers and members of Free State Agriculture. The interviews were conducted at the farmer's house by the author with the assistance of two aides. The survey collected personal information about the farmer, the cattle production system in operation as well as general supplementation practices related to the cattle production system.

The study area is undulating, varying between $1460 \mathrm{~m}$ and $1790 \mathrm{~m}$ above sea level. The mean annual precipitation varies between $524 \mathrm{~mm}$ in the northern lower lying areas and $685 \mathrm{~mm}$ in the higher lying south-eastern parts. Precipitation occurs mainly in summer (65\%) with March being the month in which the majority of the precipitation $(15 \%)$ occurs.

\subsection{STATISTICAL METHODS}

Data was captured electronically in Microsoft Excel. Analyses were done using SAS Version 9.2. Descriptive statistics namely frequencies and percentages were calculated for categorical data. Means and standard deviations or medians and percentiles were calculated for numerical data. Analytical statistics namely the analysis of variance (ANOVA) was used to compare the mean values and the mean differences between the three treatment groups. The unpaired t-test was used to compare the mean values and the mean differences between two treatment groups at a time. The paired t-test was used to investigate significant mean differences within each treatment group. A significance level (a) of 0.05 was used.

\section{RESULTS AND DISCUSSION}

The average age of the farmers was 52 years $\pm 12(\mathrm{n}=48)$ of which $15(31.1 \%)$ had a secondary education, one $(2.1 \%)$ had a tertiary certificate, 15 had a tertiary diploma $(31.3 \%)$, $14(29.2 \%)$ had a tertiary degree and three $(6.3 \%)$ had a tertiary masters qualification. The average farm size was 2769 ha \pm 2425 and the median 2000 ha. The Bonsmara $(31.3, n=$ 15), Drakensberger $(18.8 \%, n=9)$ and Simbra $(18.8 \%, n=9)$ were the most prominent breeds. 
Preventative vaccination was common practice as only one farmer did not vaccinate any of his cattle $(n=48)$. The most prevalent diseases against which farmers vaccinated were Black Quarter $(n=40,85 \%)$, Anthrax $(n=38,80.9 \%)$ and Lumpy Skin $(n=30,63.9 \%)$. A concerning trend was that only $22(46.8 \%)$ of the farmers vaccinated their heifers against Brucellosis. Brucellosis is an important disease as it is zoonotic and a controlled disease which means that suspected cases must be reported to the government veterinary services as there are specific control schemes for this disease (Olivier, 2013:1). External parasitic control was done by $45(93.8 \%)$ respondents and internal parasitic control by 35 (72.9\%) respondents.

The custom of commercial farmers (not stud breeders) breeding their own breeding bulls was commonplace ( $n=15,31.3 \%)$ with only 28 farmers (58.3\%) testing bulls for fertility and 30 farmers $(62.3 \%)$ testing for venereal diseases. Farmers breeding their own bulls was in alignment with the findings of Ramsey, Doye, Ward, Mcgrann, Falconer \& Bevers (2005:95) who found that investment in breeding livestock significantly increased per-unit costs but also increased production, however breeding-stock investment did not significantly affect cow-herd profitability.

The farmers reported the following calving percentage ranges (Figure 1): one farmer $(2.1 \%)$ between 50 and $59 \%$, three farmers $(6.3 \%)$ between 60 and 69\%, 19 farmers between 70 and 79\%, 22 farmers between 80 and 89\% and three farmers between 90 and $99 \%$. The accuracy of calving percentages reported are however questioned as only $38(79.2 \%)$ farmers had a set breeding season, 34 farmers $(70.8 \%)$ had pregnancy tests done and $28(58.3 \%)$ had an identification system (tags) for individual animals. Length of the breeding season is an indicator of management skills and intensity and longer breeding seasons have been found to increase cost and decrease production (Ramsey et al., 2005:93).

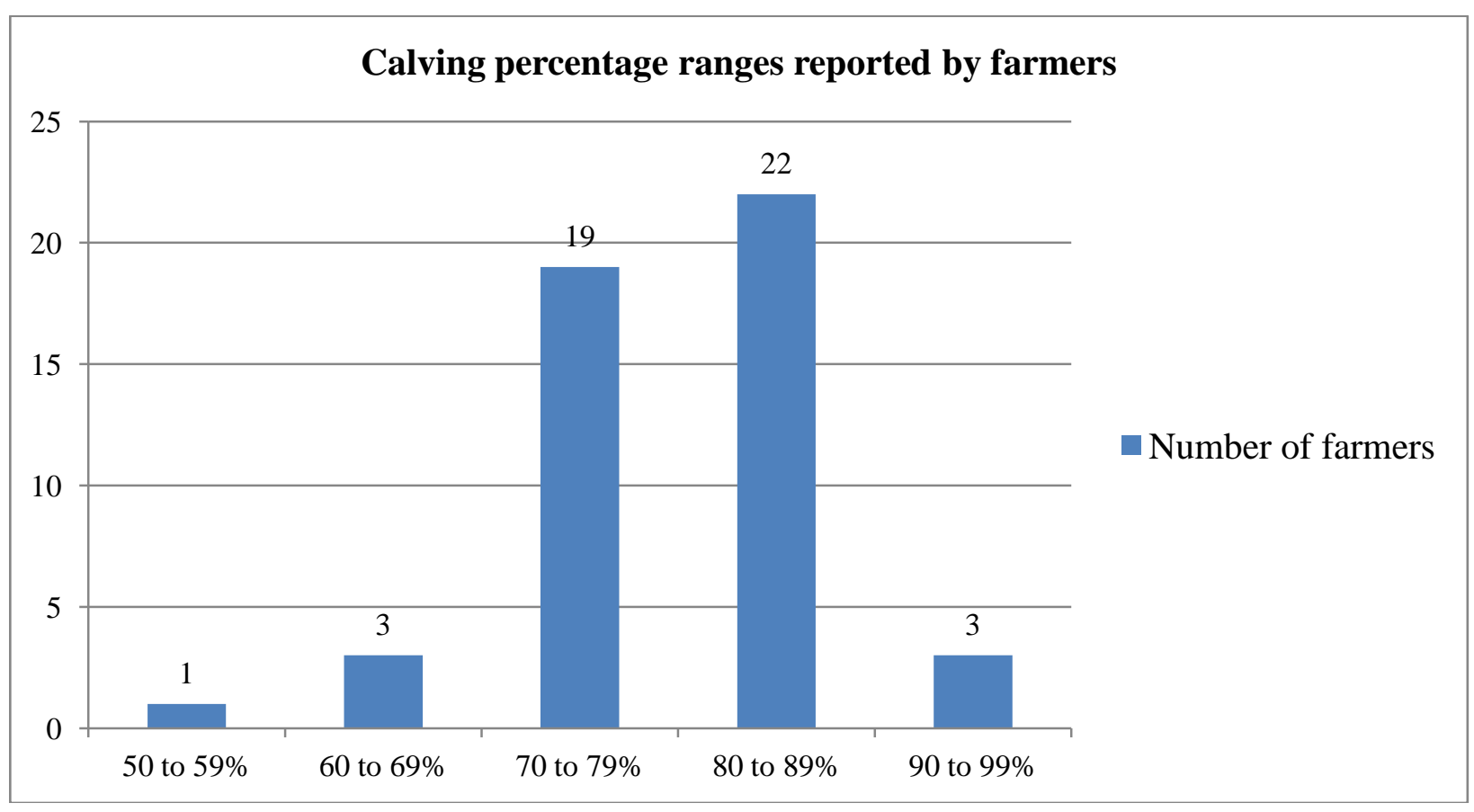

Figure 1: Calving percentage ranges of the cows reported by the farmers 
S. Afr. J. Agric. Ext.

Vol. 44, No. 2, 2016: $158-166$

DOI: http://dx.doi.org/10.17159/2413-3221/2016/v44n2a409
Foster, Fourie

\& Neser.

(Copyright)

The provision of supplements seemed to be general practice $(100 \%, n=48)$ in the district as all the farmers gave some form of supplementation to their cattle. Only $22.9 \%(n=11)$ of the farmers provided supplements according to the production status of the animals and the main reason for not doing so is that $37.8 \%(n=14)$ of the respondents believed that it complicated management and $18.9 \%(n=7)$ thought it not necessary. Supplementation should be done according to the season (Cronje, 1990; Van Pletzen, 2009:1; Ferreira, 2015:1 and Taute, 2016:21) and $44(91.7 \%)$ farmers put this advice into practice.

Groenewald (1986:184); De Brouwer et al. (1993:37), De Waal et al. (1996:33), Van Niekerk (1996:57), De Brouwer et al. (2000:50), Van Pletzen (2009:1), Taute (2016:21) and Ferreira (2015:1) recommend that phosphate $(\mathrm{P})$ supplements be used during the summer (wet season) as phosphate is the main limiting nutrient on green summer grazing. However, $6.3 \%, n=3$ of the respondents supplied no supplements at all in summer to any of their cattle (Figure 2). Of the 45 farmers who did supply supplements in summer five (11.1\%) supplied insufficient $\mathrm{P}$ due to poorly formulated supplements $(n=4)$ or only offered rock salt $(n=1)$.

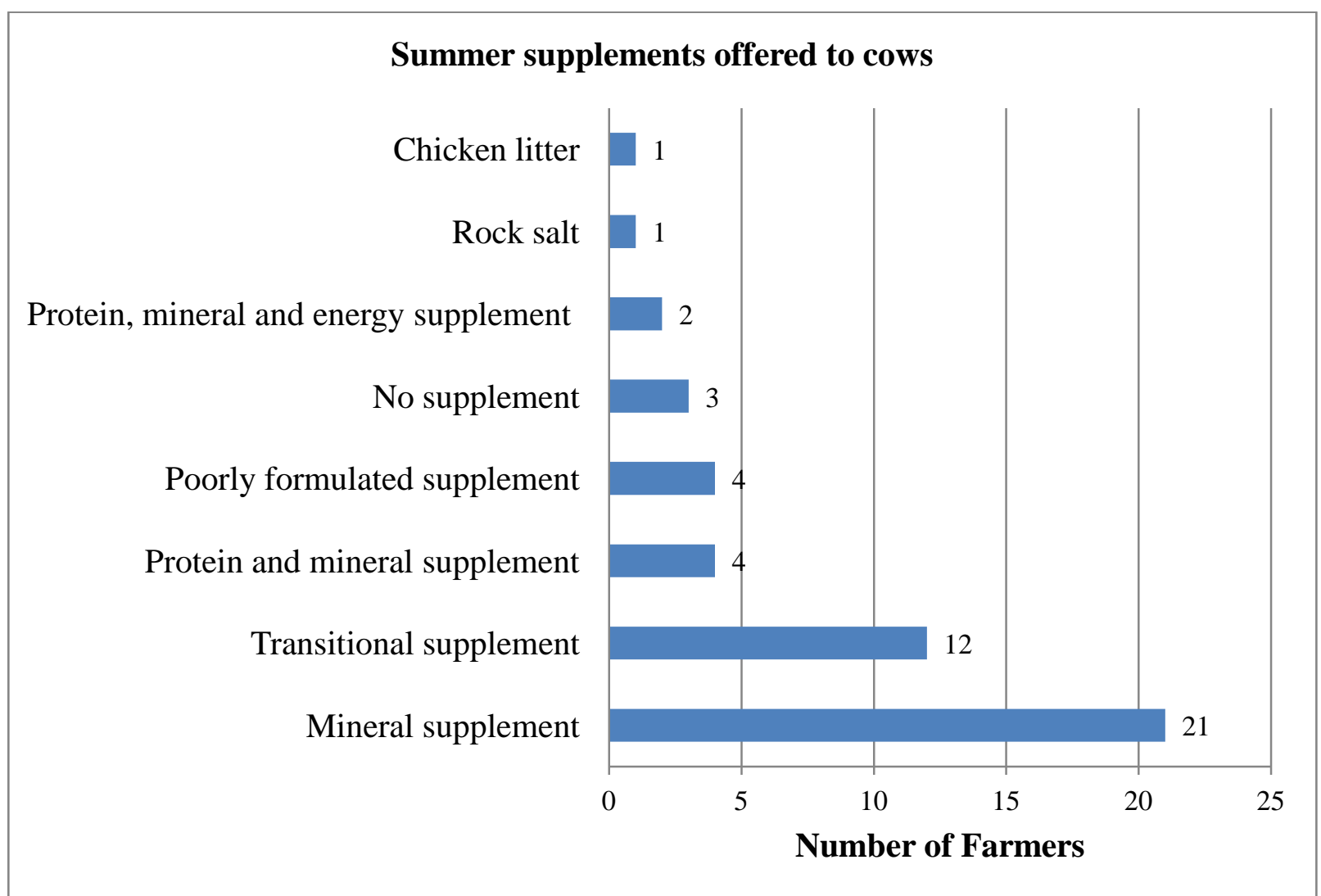

Figure 2: Supplements offered by the farmers to their cows in summer

Cows were offered the following supplements in summer by the respondents (Figure 2): namely, $21(43.8 \%)$ farmers offered a mineral supplement, 12 (25) farmers offered a transitional supplement, four $(8.3 \%)$ farmers offered a protein and mineral supplement, four (8.3\%) farmers offered a poorly formulated supplement, three $(6.3 \%)$ farmers offered no supplement, two farmers $(4.2 \%)$ offered a protein, mineral and energy supplement, one $(2.1 \%)$ farmer offered rock salt and one $(2.1 \%)$ farmer offered chicken litter. Summer supplements were offered on an ad libitum basis by 38 (84.4\%) farmers. 
S. Afr. J. Agric. Ext.

Vol. 44, No. 2, 2016: $158-166$

DOI: http://dx.doi.org/10.17159/2413-3221/2016/v44n2a409

Cows were offered the following supplements in winter by the respondents (Figure 3): namely, $81.3 \%(n=39)$ offered a protein and mineral supplement, $8.3 \%(n=4)$ offered chicken litter, 6.3\% $(n=3)$ offered a protein supplement and two $(4.2 \%)$ farmers offered a poorly formulated supplement that could not be categorized (Figure 2). More than half of the farmers (54.2\%, $n=26)$ offered supplements on an add libitum basis to their cows in winter. However, 10 respondents (20.8\%) offered less than $400 \mathrm{~g}$ supplement per animal per day.

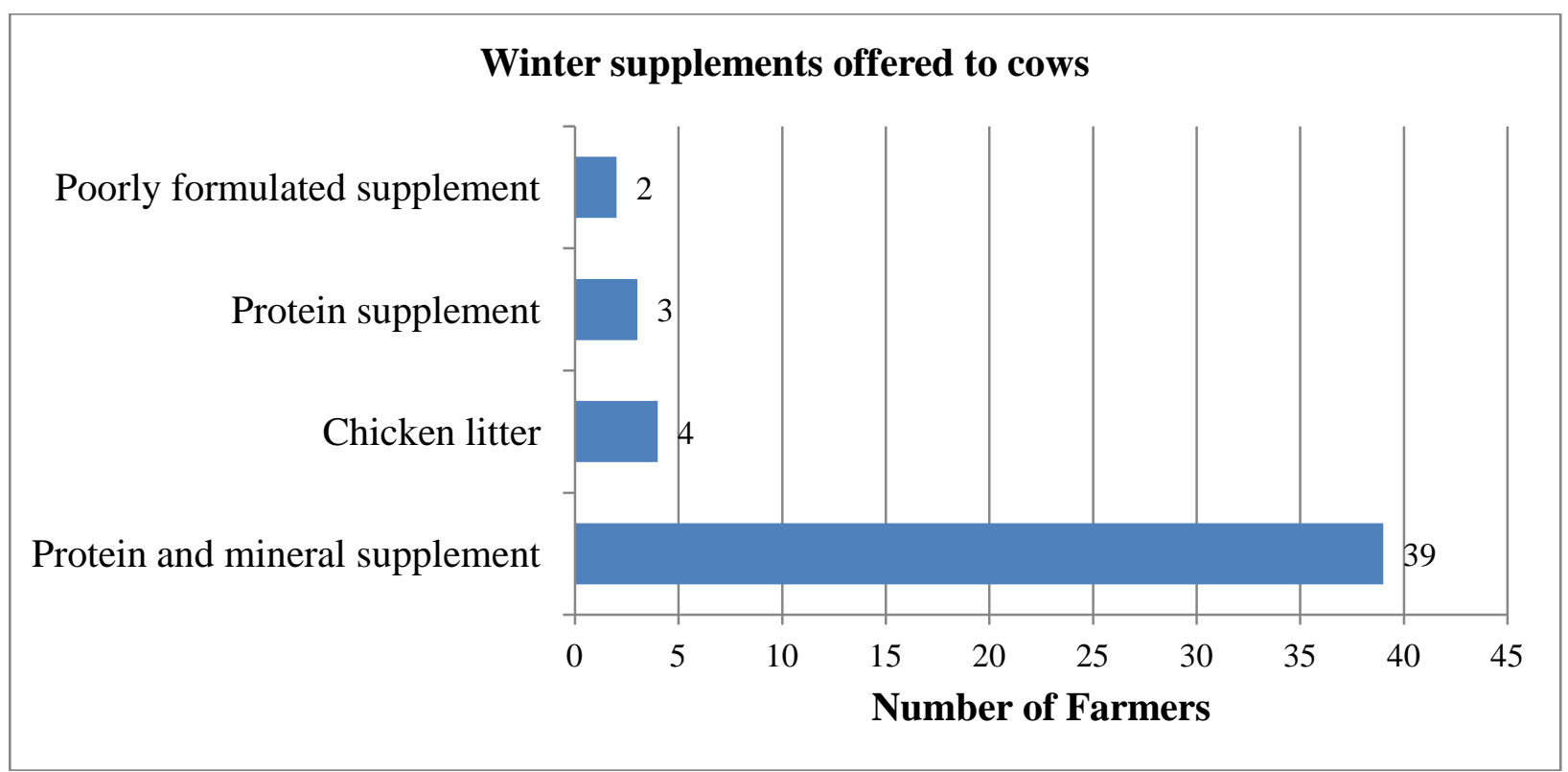

Figure 3: Supplements offered by the farmers to their cows in winter

Table 1 summarizes the winter supplements offered to the cows and the calving percentages ranges reported by farmers and Table 2 the summer supplements offered and the calving percentages reported.

Table 1: Winter supplements offered and calving percentage ranges reported by farmers.

\begin{tabular}{|l|c|c|c|c|c|}
\hline \multicolumn{1}{|c|}{ Supplements offered in winter } & \multicolumn{5}{c|}{ Calving percentage ranges reported } \\
\hline & 50 to 59 & 60 to 69 & 70 to 79 & 80 to 89 & 90 to 99 \\
\hline Protein and mineral supplement $(\mathrm{n}=39)$ & 1 & 3 & 16 & 16 & 3 \\
\hline Chicken litter $(\mathrm{n}=4)$ & & & 2 & 2 & \\
\hline Protein supplement $(\mathrm{n}=3)$ & & & 1 & 2 & \\
\hline Poorly formulated supplement $(\mathrm{n}=5)$ & & & & 2 & \\
\hline
\end{tabular}


Table 2: Summer supplements offered and calving percentage ranges reported by farmers.

\begin{tabular}{|l|c|c|c|c|c|}
\hline Supplements offered in summer & \multicolumn{5}{|c|}{ Calving percentage ranges reported } \\
\hline & 50 to 59 & 60 to 69 & 70 to 79 & 80 to 89 & 90 to 99 \\
\hline Mineral supplement $(\mathrm{n}=21)$ & 1 & 1 & 12 & 6 & 1 \\
\hline Transitional supplement $(\mathrm{n}=12)$ & & & 3 & 8 & 1 \\
\hline Protein and mineral supplement $(\mathrm{n}=4)$ & & & 1 & 2 & 1 \\
\hline Poorly formulated supplement (n=4) & & & 2 & 2 & \\
\hline No supplement (n=3) & & 2 & 1 & & \\
\hline $\begin{array}{l}\text { Protein, mineral and energy supplement (n } \\
=2)\end{array}$ & & & & 2 & \\
\hline Rock salt $(\mathrm{n}=1)$ & & & & 1 & \\
\hline Chicken litter $(\mathrm{n}=1)$ & & & & 1 & \\
\hline
\end{tabular}

It is generally accepted that beef heifers conceive at a high rate during their first breeding season provided they have grown sufficiently. However when breeding takes place while they are suckling their first calf pregnancy rate is often low, especially if heifers are bred to calf as 2-year-olds (Lishman et al., 1984:13). The nutritional requirements for growth of the young cow in addition to those for lactation are not usually met by the natural grazing available (Lishman et al., 1984:12) and the provision of supplements thus plays a vital role in their reproductive performance. The survey indicated that only six $(12.5 \%)$ farmers bred their heifers at a young age (12 to 18 months). The decision of what summer supplement to offer these heifers as first-calf-heifers thus plays a vital role as nutritional stress could affect their fall-out rate, longevity and mature cow size (Endecott, Funstont, Mullinks \& Roberts 2013:1330). According to the survey farmers breeding heifers to calve as 2-year-olds offered the following supplements to their first-calf heifers in summer, namely four (66.7\%) farmers offered a mineral supplement, one (16.7\%) farmer offered a poorly formulated supplement and one farmer $(16.7 \%)$ offered a protein, mineral and energy supplement. The farmer who offered a poorly formulated supplement reported a calving percentage ranging between 50 to $59 \%$ the four farmers offering a mineral supplement a calving percentage of 70 to $79 \%$ and the farmer who offered a protein, mineral and energy supplement a calving percentage of 80 to $89 \%$.

\section{CONCLUSIONS}

It is important to note that responses to $\mathrm{P}$ supplementation vary substantially from one area to the next; indicating that some areas are clearly $\mathrm{P}$ deficient and other areas are evidently not (De Waal, 1990:3 and De Brouwer et al., 2000:46). Read et al. (1986b:15) ruled out a subclinical P deficiency at Glen using rib-bone samples. Possible reasons for the lack of response to supplementary P feeding at Glen could have been the use of well-conserved veld and light stocking rates (7.3 ha/LSU) (Read et al. 1986a:9 and Van Niekerk, 1996:54). However, conditions of over-grazing are often applied in practice and it is questioned whether the results by Read et al. (1986a:9) could be replicated under realistic farming conditions. In light of this the results of this survey indicated that eight farmers (16.67\%) did not offer sufficient amounts of $\mathrm{P}$ to their cows during the summer, which could have a negative impact on the production and reproduction of their cow-calf production system. 
S. Afr. J. Agric. Ext.

Vol. 44, No. 2, 2016: $158-166$

Foster, Fourie

DOI: http://dx.doi.org/10.17159/2413-3221/2016/v44n2a409

\& Neser.

(Copyright)

When considering the winter supplementation programs of the farmers it appears that the majority of the respondents offer supplements according to the guidelines stipulated by animal nutritionists. Only two farmers (4.2\%) did not offer a well balanced supplement to their cows in winter. On the other hand, when scrutinizing the amounts of winter supplements offered to the cows, $10(20.8 \%)$ farmers offered less than $400 \mathrm{~g}$ supplement per cow per day and under conditions of overgrazing (which is often the case), drought or during the late winter, these amounts could be considered as insufficient.

The decision to breed heifers as yearlings involves careful consideration of the economics of production and the reproductive status, breed type, or genetic-make-up of the heifers involved (Short, Staigmiller, Bellows \& Greer 1990:94). Geographical-region differences in the age at which heifers are first exposed for breeding depend on management systems, forage quality and availability, and adaptation of respective breed types to specific environmental conditions (Short et al., 1990:94). For early mating (12 to 18 months old) to be a feasible proposition additional inputs are considered necessary (Scholtz et al., 1991:207). Only one of the six farmers who implemented early mating made the additional inputs required, offering a protein, mineral and energy supplement to his calving 2-year-old heifers and was subsequently rewarded with a good conception rate of between 80 and $89 \%$. The other five farmers did not give what is considered to be adequate supplementation of 2-year-old firstcalf-heifers by animal nutritionists and as a result reported lower calving percentages.

\section{EXTENSION IMPLICATIONS}

When considering the farmers' major educational qualification obtained and their choice of supplements offered it is interesting to note that of the eight farmers $(16.7 \%)$ who gave no supplements in summer or offered insufficient amounts of $\mathrm{P}$, seven did not have any formal agricultural qualification. In contrast, all the farmers $(n=3)$ who reported a calving percentage of between 90 and $99 \%$ had a tertiary agricultural qualification. It is therefore believed that a lack of understanding of the function of supplements by some of the farmers in the district could be the cause of what could be considered as insufficient supplementation by animal nutritionists.

It is evident that even amongst commercial farmers a gap in their technical knowledge exists. As the extension officer is particularly well positioned they can play a significant role in conveying the outcome of this study to both developing farmers and commercial farmers. This can be done through knowledge facilitation, workshops, study groups and farmer days. Kofman \& Senge (1993:23) found that farmers who are involved in farmer organizations and study groups were more likely to adopt new practices in agricultural development. According to Stevens and Terblanche (2004:49) effective farmer groups can become the "vehicle" to work collectively towards change at farm level and can help with the empowerment of farmers.

More than $20 \%$ of farmers in this study offered less than $400 \mathrm{~g}$ supplement per cow per day and under conditions of overgrazing (which is often the case), drought or during the late winter, these amounts could be considered as insufficient. Five of the six farmers who implemented early mating did not give what is considered to be adequate supplementation of 2-year-old first-calf-heifers by animal nutritionists and as a result reported lower calving percentages. More than $40 \%$ of farmers do not test their bulls for fertility. In an extension approach the risk of not testing bulls for fertility as well as the optimum level of lick supplementation must be stressed. 


\section{REFERENCES}

CRONJE, P. B. 1990. Review. Supplementary feeding in ruminants - A physiological approach. S. Afr. J. Anim. Sci., 23(3), 110-117.

DE BROUWER, C. H. M., VISSER, C. B., SCHUTTE, A. R. \& POSTMA, M. 1993. Biological and economical effects of different supplements given to beef cows on summer veld. S. Afr. J. Anim. Sci., 23(2), 31-37.

DE BROUWER, C. H. M., CILLIERS, J. W., VERMAAK, L. M., VAN DER MERWE, H. J. \& GROENEWALD, P. C. N. 2000. Phosphorus supplementation to natural pasture for beef cows in the western Highveld region of South Africa. S. Afr. J. Anim. Sci., 30(1), 43-52.

DE WAAL, H. O. 1990. Animal production from native pasture (veld) in the Free Sate Region - A perspective of the grazing ruminant. S. Afr. J. Anim. Sci., 20(1), 1-9.

DE WAAL, H. O., RANDALL, J. H. \& KOEKEMOER, G. J. 1996. The effects of phosphorus supplementation on body mass and reproduction of grazing beef cows supplemented with different levels of phosphorus at Armoedsvlakte. S. Afr. J. Anim. Sci., 26(2), 29-36.

DU PLESSIS, I., HOFFMAN, L. C. \& CALITZ, F. J. 2006. Influence of reproductive traits and pre-weaning growth rate on herd efficiency of different beef breed types in an arid sub-tropical environment. S. Afr. J. Anim. Sci., 36(2), 89-97.

ENDECOTT, R .L., FUNSTONT, R. N., MULlinKS, J. T. \& ROBERTS, A. J. 2013. Implications of beef heifer development systems and lifetime productivity. J. Anim. Sci., 91(3), 1329-1335.

FERREIRA, V. 2015. Lick Mix 87 - The economical choice for self-mixed winter licks for cattle. http://www.molatek.co.za/english/pdf/131003a.pdf

GROENEWALD, I. B. 1986. Die invloed van stikstof-, energie-, en fosforbevattende lekaanvullings op die reproduksie- en produksievermoe van koeie op natuurlike weiding. Ph.D.-proefskrif, Universiteit van die Oranje Vrystaat, Bloemfontein.

KOFMAN, F. \& SENGE, P. M. 1993. The link between individual an organizational learning. Organizational Dynamics, 22: 5-23.

LAMB, G. C. \& MADDOCK, T. 2009. Feed efficiency in cows. Cash, Cows and Calves. Florida Beef Cattle Short Course.

LISHMAN, A. W., LYLE, A. D., SMITH, V. W. \& BOTHA, W. A. 1984. Conception rate of beef cows and growth of suckling calves as influenced by date of calving and supplementary feeding. S. Afr. J. Anim. Sci., 14(1), 10-19.

LOUW, G. N., 1979. An evaluation of the application of stock lick in South Africa. S. Afr. J. Anim. Sci., (9), 133-144.

MENTZ, A. 2002. Perspektiewe oor Beesboerdery in Suider-Afrika. Highveld Herald.

MELTON, B. E. 1995. Conception to consumption. The economics of genetic improvement. In: Proceedings, The Beef Improvement Federation, Sheridan, Wyoming, pp 40-87.

OLIVIER, A. J. 2013. Brucellosis and tuberculosis. http://www.nda.agric.za/docs/Infopaks/Abrucello.pdf

PAISLEY, S. \& CHICHESTER, K. 2005. Determining the best time to wean. In: Proceedings of the 19th Range Beef Cow Symposium, Rapid City, South Dakota.

PATTERSON, D. J., WOOD. S. L. \& RANDLE, R. F. 2002. Procedures that support reproductive management of replacement beef heifers. Proceedings, The Applied Reproductive Strategies in Beef Cattle Workshop. Manhattan, Kansas. 
S. Afr. J. Agric. Ext.

Vol. 44, No. 2, 2016: $158-166$

DOI: http://dx.doi.org/10.17159/2413-3221/2016/v44n2a409
Foster, Fourie

\& Neser.

(Copyright)

RAMSEY, R., DOYE, D., WARD, C., MCGRANN, J., FALCONER, L. \& BEVERS, S. 2005. Factors affecting beef cow-herd costs, production, and profits. J. Agric. and App. Econ., 37(1), 91-99.

READ, M. V. P. \& ENGELS, E. A. N. \& SMITH, W. A. 1986a. Phosphorus and the grazing ruminant. 2. The effects of supplementary $\mathrm{P}$ on cattle at Glen and Armoedsvlakte. S. Afr. J. Anim. Sci., 16(1), 7-12.

READ, M. V. P. \& ENGELS, E. A. N. \& SMITH, W. A. 1986b. Phosphorus and the grazing ruminant. 3. Rib bone samples as an indicator of the P status of cattle. S. Afr. J. Anim. Sci., 16(1), 13-17.

SCHOLTZ, M. M, LOMBARD, P. E. \& ENSLIN C. B. 1991. A note on the early calving of beef heifers. S. Afr. J. Anim. Sci., 21(4), 206-209.

SHORT, R. E., STAIGMILLER, R. B., BELLOWS, R. A. \& GREER, R. C. 1990. Breeding heifers at one year of age: Biological and economic considerations. In: Proceedings of the 39 ${ }^{\text {th }}$ Annual Beef Cattle Short Course, 93-106. University of Florida, Gainesvelle.

STEVENS, J. B. \& TERBLANCHÉ, S. E. 2004. Sustainable agriculture development through effective farmer groups. S. Afr. J. Ext. Volume: 33 Pages: 40-49.

TAUTE, A. 2016. Yara Product Guide.

http://www.kkan.com/docs/Animal\%20Nutrition\%20Product\%20Guide\%20EN\%20mail . $\mathrm{pdf}$

VAN NIEKERK, B. D. H. 1996. Limiting nutrients in supplementary feeding. Bul. Grassl. Soc. Southern Africa, 7(1), 51-59.

VAN PLETZEN, H. (2009). Beef production from the veld offers great opportunities. http://www.voermol.co.za/en/news/technical/BEEF_PRODUCTION_FROM_THE_VEL D_OFFERS_GREAT_OPPORTUNITIES/default.aspx

WALKER, J. \& PERRY, G. 2007. Cow condition and reproductive performance. In: Proceedings of the 20th Range Beef Cow Symposium, Fort Collins, Colorado. 